\title{
MECOM wt Allele
}

National Cancer Institute

\section{Source}

National Cancer Institute. MECOM wt Allele. NCI Thesaurus. Code C52876.

Human MECOM wild-type allele is located within 3q24-q28 and is approximately $64 \mathrm{~kb}$ in length. This allele, which encodes MDS1 and EVI1 complex locus protein EVI1, plays a role in the modulation of transcription by RNA polymerase II. Chronic myelogenous leukemia with or without associated blastic crisis, myeloid or undifferentiated leukemia, and myelodysplastic syndrome related to therapy are all associated with complex chromosomal rearrangements of this gene. 